\title{
Modus vivendi Johna Graye jako alternativní projekt liberálního myšlení: akceptace hodnotového konfliktu coby základu politična
}

\author{
John Gray's modus vivendi as an alternative project of liberal thought: acceptation \\ of value conflict as a base of the political
}

\author{
Aneta Květinová \\ Fakulta filozofická \\ Univerzita Pardubice \\ Studentská 84, 53210 Pardubice \\ aneta.kvetinova@seznam.cz
}

\begin{abstract}
Abstrakt/Abstract
Studie se zabývá analýzou politické teorie modu vivendi britského politického filosofa Johna Graye, přičemž za její hlavní cíl lze považovat především určení autorovy ideologické pozice v kontextu liberálního myšlení, jakož i posouzení koherence Grayovy teorie s koncepcí liberalismu strachu. Na základě kritické reflexe prevevažujícího univerzalistického pojetí liberalismu článek identifikuje a analyzuje stěžejní atributy Grayova specifického uchopení liberální teorie v podobě ideálu modu vivendi, etické teorie hodnotového pluralismu, univerzálního minima a hodnoty tolerance. V návaznosti na tuto identifikaci je následně zkoumán i etický rozměr Grayovy politické teorie, jehož charakteristika umožňuje zhodnotit, do jaké míry lze autorovu teorii interpretovat $\mathrm{v}$ kontextu liberálního myšlení. V této souvislosti se studie rovněž snaží ukotvit Grayovu tvorbu v širším rámci alternativních projektů liberální teorie, když usiluje o prokázání principiálních paralel mezi Grayovým politickým modelem a politickým myšlením Bernarda Williamse jakožto stěžejním představitelem tzv. liberalismu strachu. Výzkum těchto paralel pak přspívá především $\mathrm{k}$ nastolení otázek souvisejících $\mathrm{s}$ možností důsledného odlišování politické a morální teorie a chápání konfliktu jakožto neodmyslitelné součásti politické reality v rámci současného liberalismu.
\end{abstract}

The paper aims to analyse the political theory of modus vivendi by political philosopher John Gray and to determine the ideological standpoints of Gray's theory within the context of liberal thought as well as to assess its coherence with the concept of liberalism of fear. On the basis of a critical reflection of the prevailing universalistic conception of liberalism, the study identifies and analyses essential attributes of Gray's specific but controversial political theory: the ideal of modus vivendi; ethical theory of value pluralism; universal minimum and the value of toleration. Having interpreted all those main parts of the concept, the study is supposed to clarify also the ethical dimension of Gray's theory which makes it possible to decide to what extent the author might be identified as a liberal thinker. In this regard, the study endeavours to embed Gray's thought in a broader framework of alternative projects of liberal theory by demonstrating fundamental parallels between Gray's model and political thought of Bernard Williams as the main theoretician of liberalism of fear. Investigations of those parallels thus contributes towards articulating questions concerning the possibility of consistently distinguishing between the political and the moral 
theory as well as perception of a conflict as an ineradicable part of political reality in the framework of contemporary liberalism.

Politická teorie britského filosofa Johna Graye představuje v aktuálním politickém myšlení svébytnou, obtížně uchopitelnou a mnohdy rozpačitost vzbuzující koncepci, nebot' její autor usiluje o zdánlivě neslučitelné cíle, spočívající jak v důsledném zpochybnění obecně přijímaných společensko-vědních předpokladů současného politického myšlení, tak i v jejich osobitém rozvíjení prostřednictvím promýšlení alternativních teoretických východisek. Vzhledem k tomu, že Gray působí nejen jako filosof a politický teoretik, ale také jako společenský komentátor píšící popularizační texty, není vždy snadné stanovit pomyslnou dělicí čáru mezi jeho díly určenými pro akademickou sféru a mezi texty pro široké publikum. Právě Grayův esejistický styl, jakož i četné využívání historických exkurzů a neustálá modifikace vlastních stanovisek navíc znesnadňuje interpretaci autorovy ideové orientace. Abychom si učinili představu o Grayově častém a leckdy zcela antagonistickém střídání názorových pozic, lze v jeho filosofii mapovat určitou ideologickou cestu, na jejímž počátku v polovině sedmdesátých let je zřejmá autorova víra v liberalismus Johna Stuarta Milla. Ta se však u Graye bouřlivě transformovala - nejprve postupným tíhnutím k myšlení Fridricha Hayeka a neoliberalismu, posléze přesunem ke konzervatismu Michaela Oakeshotta a následně k sympatiím vưči politické činnosti Tonyho Blaira a programu New Labour. Po této ideologické proměně, zahrnující neoliberální, konzervativní i socialistické tendence, Gray zaměřil své akademické úsilí dvojím směrem, když se jednak soustředil na formulování vlastní teorie liberalismu, stojící v opozici k dominantní formě této ideologie reprezentované především Johnem Rawlsem a Ronaldem Dworkinem, jednak si osvojil principy nihilismu, který je spjat s Grayovou náklonností k antihumanismu a teorii Gaia Jamese Lovelocka. ${ }^{1}$

Samotnou Grayovu politickou filosofii lze charakterizovat jako soustavnou kritiku v moderní době převažujícího proudu liberálního myšlení, založeného na ideji racionálního konsensu a činícího si nárok na univerzální autoritu konkrétní morálky. ${ }^{2}$ Gray tento druh liberalismu považuje v současném pluralitním světě za nevyhovující a navrhuje proto svou teorii modu vivendi ${ }^{3}$ jakožto ideálu mírové koexistence

\footnotetext{
${ }^{1}$ Blíže např. Horton \& Newey (2007, s. 2).

${ }^{2}$ Ačkoli kritika současného dominantního proudu liberalismu je v politické diskusi poměrně častým trendem, je třeba zdůraznit, že Gray se svým př́stupem vymyká běžné argumentaci většiny myšlenkových proudů, tudíž jej nelze přiřadit ani ke kritice klasických liberálů jako je např́klad John Lucas, konzervativců jako je Robert Nisbet či komunitaristů v čele s Michaelem Sandelem.

${ }^{3}$ Označení modus vivendi je přitom v Grayových textech často užíváno jako synonymum pro termín agonistického liberalismu. Gray pojmem agonistického liberalismu původně označoval
} 
jednotlivých životních způsobů ${ }^{4}$ v rámci jednoho společenství či státu i mezi státy navzájem. Podmínkou pro uskutečnění politiky modu vivendi je tedy existence minimálně dvou stran, které se navzdory svým odlišným hodnotovým přesvědčením rozhodly ke vzájemné toleranci. Základním výchozím předpokladem této Grayovy koncepce je přitom etická teorie hodnotového pluralismu, dle níž platí „že lidé mohou žít a prospívat mnoha způsoby, a to způsoby někdy tak protikladnými, že je nelze hodnotově nijak srovnávat, “ pročež žádný z těchto způsobů nemůže být považován za univerzální, respektive za ideální pro všechny lidské bytosti. ${ }^{5} \mathrm{Z}$ toho vyplývá, že hodnotový konflikt je vzhledem $\mathrm{k}$ nesouměřitelnosti hodnot a životních způsobů neodmyslitelnou součástí lidských životů, znemožňující dospět k jakémukoli racionálnímu konsensu. To přivádí Graye k závěru, že je třeba opustit veškeré univerzalistické tendence liberalismu a přijmout namísto toho alternativní projekt modu vivendi založený na vzájemné toleranci, jež umožňuje hledat podmínky mírového soužití jednotlivců, skupin i životních způsobů s odlišnými hodnotami. ${ }^{6}$

Vzhledem k takto stanoveným cílům Grayovy teorie, jakož i ke kritickému postoji autora vưči př́ilišnému etickému zatížení liberální tradice je na místě klást si otázku, zda má Grayem předkládaná koncepce modu vivendi rovněž určitý etický rozměr či nikoliv, tedy zda lze v jejím rámci identifikovat dominantní normativní hodnoty, osobující si formativní charakter ve vztahu k politické sféře, či zda je možné koncepci modu vivendi považovat za hodnotově zcela neutrální. S ohledem na to je žádoucí posoudit platnost Grayova tvrzení, že ,modus vivendi je projektem politickým, nikoliv morálním ideálem. ${ }^{\text {"7 }} \mathrm{V}$ tomto směru je přitom nutné zvážit, zda je autorovým cílem tematizovat určité rozlišení mezi politickou a morální teorií, nebot' jak budu dále tvrdit, v Grayově politické teorii modu vivendi lze nalézt určité paralely s liberalismem strachu, potažmo s

koncepci I. Berlina, viz Gray (1993), poté však i svou vlastní teorii, viz Gray (1995). Nicméně v pozdních textech, viz Gray (2004), se Gray již drží označení své politické filosofie jako liberalismu modu vivendi či jen modu vivendi, které používá i tato práce.

4 Slovní spojení ,životní způsob“ (life form) Grayovi slouží k označení rozmanitých, nesouměřitelných a hodnotově specifických stylů života, které mohou skupiny jedinců vést. Životním způsobem je tedy pro Graye například způsob života emancipované ženy v Západním světě, který je hodnotově nesouměřitelný se stylem života ženy v muslimském prostředí. Mezi jednotlivými životními způsoby přitom probíhá neustálá interakce, proto je obtížné jasně je definovat, př́ípadně mezi nimi určit rozdíl. Gray se přesto snaží předložit několik kritérií, na jejichž základě je možné určitý životní způsob vymezit: 1) musí být veden větším počtem lidí, nikoli pouze jednotlivcem, 2) musí být předáván z generace na generaci, 3) musí být smysluplný a uznáván ostatními jedinci, 4) musí vylučovat některé jedince a musí se vyznačovat konkrétními zvyky, přesvědčeními a hodnotami. Blíže viz Gray (2004, s. 21).

${ }^{5}$ Gray (2004, s. 15).

${ }^{6}$ Tamtéž, s. 38.

${ }^{7}$ Tamtéž, s. 38. 
myšlenkami Bernarda Williamse, jejichž cílem je odmítnout nadřazenost morálky nad političnem. ${ }^{8} \mathrm{~S}$ tím souvisí rovněž druhá otázka, jež se věnuje problému Grayova ideového zaměření - s ohledem na Grayovo uchopení modu vivendi je totiž žádoucí rozhodnout, zda je možné Graye považovat za liberálního myslitele, či zda jeho teorie nabízí vůči liberalismu spíše určitou alternativu. ${ }^{9}$ Právě otázka souladu autorových stěžejních idejí s ústředními principy liberálního politického myšlení se v tomto ohledu úzce vztahuje k základnímu výzkumnému záměru této studie, jelikož výše avizované posouzení míry etického rozměru Grayovy politické teorie nutně vyžaduje identifikaci jeho pozice právě ve vztahu ke klasickému liberálnímu kontextu.

\section{Dvě tváře liberalismu}

Vzhledem k tomu, že Gray dospívá k formulaci vlastní politické teorie cestou kritického zkoumání dosavadní tradice liberálního myšlení, přičemž zároveň nepopírá ambici vytvořit vůči tomuto domněle nevyhovujícímu mainstreamovému způsobu liberálního uvažování o společnosti relevantní alternativu, je v prvé řadě žádoucí věnovat pozornost právě Grayovu vymezení této dominantní formy liberalismu. Dříve než tak učiníme, je však vhodné zdůraznit Grayovo - pro následně představenou „prowilliamsovskou“ interpretaci zásadní - tvrzení, že pro pochopení liberalismu je nutné porozumět

${ }^{8}$ Pojem „politično“ či „bytostné politično“ bude v této studii nadále užíván pro označení určité výchozí situace umožñující vznik podmínek a základních potřeb politiky coby procesu vzájemného vyjednávání. Politično je tedy odlišné od politiky jakožto konkrétního výkonu moci, nebot' ve své podstatě představuje její základní předpoklad, když vymezuje základní kategorie aktérů a vytyčuje prostor, v němž může politická aktivita probíhat. Tento význam přiděluje političnu i řada dalších teoretiků politického myšlení, mezi jinými např́klad Colin Hay, který v této souvislosti hovoří o „utváření kontextu ... a schopnostech aktérů předefinovat parametry toho, co je společensky, politicky a ekonomicky možné pro aktéry ostatní ... čímž je zároveň definován rozsah jejich alternativ.“" Hay (2002, s. 74).

${ }^{9}$ Zde je třeba zdůraznit, že posouzení, zda lze Graye přiřadit k liberální tradici myšlení, je značně obtížné, nebot' vymezení liberalismu vykazuje ve vývoji politické teorie notně vágní a zároveň kontroverzní atributy. I přes široké spektrum různých proudů uvnitř liberální tradice, jež logicky vyplývá z uvedené benevolence definičního vymezení a jež zároveň vede $\mathrm{k}$ podstatným rozdílům např́klad mezi klasickým, sociálním a moderním liberalismem, lze pro účely této studie identifikovat liberální směr myšlení v jeho nejobecnější formě, na níž se obvykle shoduje valná většina jeho zastánců. V takovém př́ípadě můžeme za základní atributy liberálního kánonu uvažování o společnosti považovat především principy individuální svobody a autonomie, založené na myšlence nezcizitelných lidských práv a soukromého prostoru, striktně odlišeného od veřejné sféry. Na základní rovině pak v liberální teorii panuje obvykle i shoda v otázce úlohy státu, jenž nemá představovat hodnotovou autoritu, ale nestranného arbitra, umožňujícího svým občanům životní realizaci dle jejich vlastních představ, s čímž se pojí pro liberalismus neodmyslitelný důraz kladený na hodnoty pluralismu a tolerance. Pokládáme-li v této studii otázku po Grayově př́ślušnosti k liberální tradici, je dobré zdůraznit, že odpověd' vyžaduje v prvé řadě posoudit, do jaké míry autorova teorie konvenuje právě s výše zmíněnými principy, respektive zda je v některém ohledu zásadně popírá. Blíže viz Heywood (2005, s. 39-40). 
kulturnímu a politickému prostředí, v jehož rámci se v období raného novověku formoval. Ačkoliv liberalismus dle Graye nemá žádnou konkrétní neměnnou podstatu, můžeme u něho identifikovat řadu stěžejních rysů, které je možné plně pochopit pouze z hlediska určité historické perspektivy. ${ }^{10}$ Tento Grayův důraz na historickou podmíněnost liberalismu či jakékoli jiné teorie lze přitom považovat právě za jeden z ústředních znaků, na jehož základě autor odlišuje převažující proud liberálního myšlení, zakládající se na určité abstraktní teorii a jistých morálních principech, od své vlastní teorie modu vivendi, která se snaží vycházet jak z proměnlivé dějinné situace, tak z uvědomění si existence bytostného politična.

V této souvislosti je namístě akcentovat skutečnost, že Grayovo úsilí o definici liberalismu prošlo několika vývojovými fázemi, během nichž autor svůj postoj k liberální tradici do značné míry revidoval. V díle Liberalismus totiž nejdříve připustil platnost běžného rozlišení mezi klasickým a moderním liberalismem, jež však dle jeho mínění nemá vliv na skutečnost, že liberalismus představuje jednotnou tradici, kterou lze charakterizovat určitým stálým pojetím člověka a společnosti, vyznačujícím se čtyřmi základními prvky: individualismem, univerzalismem, meliorismem a egalitarismem. ${ }^{11}$ Tyto principy Gray následně v díle Post-liberalism: Studies in Political Thought označuje souhrnným názvem jako „liberální syndrom“. Ten se dle něho projevuje jak u klasických, tak i moderních či egalitárních liberálů, které od sebe tudíž nelze jednoznačně oddělovat. ${ }^{12}$ Dosud konečnou podobu Grayova vymezení liberálního kánonu uvažování pak najdeme v jeho publikaci Dvě tváře liberalismu, kde autor na základě dvou neslučitelných ideálů tolerance vymezuje existenci dvou odlišných proudů liberálního myšlení - převažující liberalismus univerzálního režimu a doposud minoritní liberalismus mírového soužití. ${ }^{13}$

První zmíněné pojetí liberalismu univerzálního režimu či univerzalistického liberalismu ${ }^{14}$ Gray definuje prostrednictvím principu tolerance jako hledání určité ideální podoby života, v rámci níž jsou liberální instituce chápány jako aplikace univerzálních principů. Gray do této tradice myšlení řadí širokou škálu fillosofů jako například J. Locka, I. Kanta, J. Rawlse, R. Dworkina, F. Hayeka a další. Naproti tomu

${ }^{10}$ Gray (1999, s. 7).

${ }^{11}$ V originále vydáno poprvé v roce 1986. Gray (1999, s. 8-9).

${ }^{12}$ Gray (1993, s. 285).

${ }^{13}$ Gray (2004, s. 10).

14 Gray užívá termín „liberalismus univerzálního režimu“ synonymně s označením „univerzalistické pojetí liberalismu“ či ,univerzalistický proud liberalismu“. V zájmu lepší orientace se budu v této studii pro označení daného typu liberalismu nadále držet spíše druhého zmíněného termínu. Nutno dodat, že Grayův termín „univerzalistický proud liberalismu“ v podstatě odpovídá obsahovému vymezení klasického liberalismu. 
druhý proud liberálního myšlení, tedy liberalismus mírového soužití autor na základě tolerance vymezuje jako hledání mírových podmínek mezi rozdílnými životními způsoby. Tuto tradici liberalismu pak dle Graye reprezentují především myslitelé jako T. Hobbes, D. Hume, I. Berlin a M. Oakeshott. Gray v tomto ohledu zdůrazňuje, že univerzalistický proud liberalismu není schopen poskytnout návod, jak žít ve společnosti, kde existuje mnoho životních způsobů, ačkoli v současné době

„V důsledku hromadné migrace, nových komunikačních technologií a neustálého kulturního experimentování obsahují téměř všechny společnosti několik životních způsobů, přičemž mnoho lidí vede více než jeden z nich“. 15

Na základě uvedeného rozlišení dvou podob liberální tradice Gray formuluje klíčovou tezi své teorie, a sice že za podmínek moderního pluralismu bychom měli opustit převažující univerzalistické pojetí liberalismu a odmítnout tak touhu docílit racionálního konsensu ve věci liberálních hodnot. Namísto toho bychom dle Graye měli přijmout skromnější, byt' normativně limitovaný politický ideál modu vivendi, navazující na druhý zmíněný a doposud méně frekventovaný proud liberalismu mírového soužití. ${ }^{16}$

\section{Kritika univerzalistického pojetí liberalismu}

Pro vyjasnění Grayova stanoviska, odmítajícího dosud hlavní univerzalistický proud liberálního myšlení ve prospěch alternativního ideálu modu vivendi, je žádoucí zaměřit se na Grayovu kritiku výše zmíněného liberálního syndromu. Na jeho základě autor spojuje univerzalistický proud liberalismu stzv. osvícenským projektem, jenž je neoddělitelně spjat $s$ filosofií historie a myšlenkou pokroku a jenž zároveň tvoří určitou červenou nit liberálního myšlení ve všech jeho tradičních formách od Locka, Kanta, Johna Stuarta Milla až k pozdnímu Rawlsovi. ${ }^{17}$ Je přitom nutné vzít na vědomí, že ačkoliv má Gray tímto projektem na mysli určitý souhrn ideových principů, které si liberální tradice původně skutečně osvojila v průběhu historické epochy osvícenství, zařazuje do jeho rámce i značné množství pozdějších autorů, kteří dle něho vykazují jednoznačnou závislost na ideologických rysech osvícenského projektu, čímž je možné ztotožnit je právě s oním univerzalistickým pojetím liberalismu. Je tudíž zřejmé, že Gray v tomto směru používá pojem „osvícenství“ v notně volnějším významu, než jak je obvykle chápán, tedy nikoli jako přesně ohraničenou etapu v dějinách politického myšlení, nýbrž jako určitý široký inspirační základ moderní liberální teorie.

${ }^{15}$ Gray (2004, s. 9-10).

${ }^{16}$ Horton (2007, s. 44).

${ }^{17}$ Gray (1995, s. 65-66). 
Zaměříme-li se nyní na Grayem zdůrazňované konstitutivní prvky liberálního syndromu, je v prvé řadě třeba věnovat pozornost individualismu, tedy ideji, že jedinec je principiálně nadřazen jakémukoli kolektivu, nebot’ jsou to právě individuální stavy mysli, pocity či aspekty života lidských bytostí, jež mají rozhodující hodnotu, a musí být tudíž vždy stavěny výše než kolektivní instituce a životní způsoby. ${ }^{18}$ Gray však namítá, že individualismus nemá žádné výlučné postavení, nebot' je pouze jednou z možných forem lidského prospívání, která sice jedincům umožňuje docílit mnohých dober, avšak dosažení velké části jiných naopak zabraňuje. ${ }^{19} \mathrm{~V}$ souvislosti s kritikou individualismu Gray přitakává filosofii komunitarismu, která mimo jiné postuluje, že liberální tradice činí z člověka prázdný subjekt bez historie či vlastní identity. ${ }^{20}$ Gray nicméně kromě liberálního pojetí individuálního subjektu odmítá i komunitaristický ideál definující jedince na základě jeho příslušnosti k určitému společenství. ${ }^{21}$ Domnívá se totiž, že identitu lidí utváří fakt, že ,,vedou nikoliv jeden, ale několik životních způsobů, a to se všemi jejich konflikty“, 22 jež se však univerzalistický liberalismus stejně jako komunitarismus snaží ze svého středu vymýtit.

Další klíčový rys liberálního syndromu tvoří dle Graye meliorismus, čili představa, že veškeré společenské instituce a politická zř́zení jsou prostřednictvím lidského rozumu zcela zdokonalitelná. ${ }^{23}$ Jak Gray poukazuje, víra v pokrok, jakož i v konečné sjednocení rozdílných kulturních forem v jednu univerzální civilizaci opět odkazují k jádru osvícenského projektu, z něhož vychází většina současných liberálních koncepcí. Gray se přitom vymezuje vůči jakékoli ideji dokonalosti, poněvadž zdůrazňuje pluralitu životních způsobů a kulturních forem, které nelze redukovat na jediný princip či obsáhnout $\mathrm{v}$ určitém souboru dokonalých a univerzálně platných institucí. $^{24}$ Moderní společnosti v sobě totiž dle Graye zahrnují natolik rozdílné životní

${ }^{18}$ Gray (1993, s. 286).

${ }^{19}$ Tamtéž, s. 307.

${ }^{20}$ Gray (2004, s. 157).

${ }^{21} \mathrm{Na}$ tomto místě je třeba poukázat na skutečnost, že činí-li Gray z komunitarismu celistvou tradici myšlení, vytváří si do značné míry umělého nepř́itele, nebot' i v rámci komunitarismu existuje pluralita různých př́ístupů, jež je patrná např́klad na odlišném pojetí subjektu u Charlese Taylora a Michaela Sandela. Tato tendence chápat obdobný způsob kritiky liberálního myšlení jednolitým způsobem, je nicméně i navzdory námitkám autorů jako jsou právě Taylor či Will Kymlicka v politické teorii zcela běžná. Blíže viz Taylor (1997).

${ }^{22}$ Gray (2004, s. 158).

${ }^{23}$ Gray (1993, s. 286).

${ }^{24}$ Gray (1995, s. 126). 
způsoby, že tvrzení o jednotné modernizaci jejich institucí může být považováno pouze za záležitost víry, postrádající jakékoli historické opodstatnění. ${ }^{25}$

Tím se dostáváme ke třetímu základnímu prvku liberálního syndromu, a to $\mathrm{k}$ egalitarismu, dle něhož lze všem lidským bytostem přiznat stejný morální status, nebot' egalitarismus ve své podstatě popírá význam přirozené morální či politické hierarchie mezi lidmi. ${ }^{26}$ Ačkoli Grayovým zájmem není podporovat jakýkoli druh nerovnosti, domnívá se, že existuje mnoho způsobů lidského prospívání, jež jsou neslučitelné s liberálním ideálem rovnosti. Některá dobra jsou totiž dle autora liberálním režimem potlačována, jelikož jsou závislá na zděděné hierarchii či na nuceném podřízení, předpokládajícím zakotvení lidí v určitých rolích, které utváří jejich identitu. ${ }^{27}$ Rovnost je přitom podle Graye pouze jednou hodnotou z mnoha žádoucích, a nelze jí oprávněně přisuzovat výjimečné postavení. Tento fakt se autor snaží doložit poukazem k uspořádání antických společností, v nichž byla idea rovnosti značně oslabená, nebo zde dokonce zcela chyběla. ${ }^{28}$ Gray k tomu dodává, že až moderní doba se svým urputným úsilím o dosažení harmonie vnesla do společenského a politického života požadavek uniformity namísto toho, aby se zaměřila na uznání všeobecných rozdílů a nevyhnutelného konfliktu. ${ }^{29}$

To nám umožňuje zaměřit se na poslední a pro Grayovu kritiku dle mého soudu nejdůležitější konstitutivní prvek liberálního syndromu, a sice univerzalismus. Dle něho platí, že existují určitá důležitá práva a povinnosti, jež jsou platná pro všechny jedince, a to pouze na základě jejich titulu jakožto lidských bytostí, nehledě na odlišné kulturní formy a specifické historické okolnosti, v nichž se lidé nachází. ${ }^{30}$ Liberalismus je pak dle takového názoru považován za nejlepší politické uspořádání pro celé lidstvo, nebot' svými principy ztělesňuje jediné legitimní vyjádření univerzálních hodnot. Proti obdobným univerzalistickým tendencím, které se objevily již v době osvícenství, se Gray ostře vymezuje, nebot' jeho pozice hodnotového pluralismu je jakousi rozvratnou doktrínou, narušující veškerá tvrzení o ideálním lidském životě. Gray v této souvislosti postuluje, že existuje mnoho různých způsobů, jimiž mohou lidé prosperovat, pročež liberalismu jako politické teorii nelze přisuzovat univerzální autoritu. Ačkoli mají dle autora liberální univerzalisté pravdu v tom, že existují určité univerzální hodnoty, mýlí se, když je ztotožňují s vlastními ideály - liberální hodnoty patří do celé řady životních

\footnotetext{
${ }^{25}$ Gray (2004, s. 36-37).

${ }^{26}$ Gray (1999, s. 8).

${ }^{27}$ Gray (1993, s. 299).

${ }^{28}$ Blíže např. Bleicken (2002, s. 346-370).

${ }^{29}$ Gray (1993, s. 12).

${ }^{30}$ Tamtéž, s. 286.
} 
způsobů a není proto nutné ztotožňovat jejich realizaci pouze s jedním univerzálním režimem. ${ }^{31}$ Tomuto Grayovu stanovisku odpovídá i jeho vymezení univerzálních forem dobra a zla, které tvoří jakousi obecnou lidskou zkušenost, neustále přítomnou v lidských dějinách a vyjádřenou v příslušných kategoriích dané doby bez ohledu na konkrétní režim, v němž se jedinci právě nachází.

Gray se navíc domnívá, že univerzální hodnoty jsou ve vzájemném konfliktu, což je také důvod, proč nemohou představovat východisko pro uskutečnění osvícenského ideálu univerzální civilizace: ,... mohou-li si univerzální hodnoty konkurovat, pak něco takového jako ideální život nemůže existovat. “32 V této souvislosti se ovšem nabízí otázka, jestli Gray ztotožňuje univerzální hodnoty s jím postulovanými univerzálními formami dobra a zla, a zda tedy i tyto univerzální formy mohou být ve vzájemném konfliktu. Domnívám se, že v tomto případě se odkrývá Grayova terminologická nepřesnost, nebot' autor užívá pojem univerzálních forem dobra a zla jako synonymum pro univerzální hodnoty, přičemž obě tato označení chápe v jistém smyslu spíše po Williamsově vzoru jako určitá základní přesvědčení, respektive politické banality. Tyto politické banality jsou totiž dle Williamse - stejně jako Grayovy univerzální formy dobra a zla - univerzáliemi, jež jsou jakožto primární formy lidské zkušenosti v odlišných podobách přítomné v každé fázi historického vývoje společnosti, a jež tvoří výchozí bod pro jakékoli uvažování v politickém kontextu. ${ }^{33}$ Tak jako Williams na základě svého tvrzení o prvotní existenci politických banalit odmítá vycházet při formulování své koncepce $\mathrm{z}$ předem stanovených morálních postulátů a univerzálních pravidel abstraktních teorií, snaží se i Gray svým důrazem na univerzální a všem lidským bytostem reálně přístupné formy dobra a zla zdůraznit úlohu politična a nevhodné moralizující tendence liberálních teorií. Jak navíc Gray tvrdí, vzhledem k tomu, že dosavadní dominantní forma liberalismu není schopna vyřešit nároky konfliktních hodnot, respektive možných konfliktů univerzálních forem dobra a zla, měli bychom dle autora zanechat veškerého úsilí o vytvoření teoretického systému univerzálních principů a namísto toho pohlížet na liberalismus vintencích modu

${ }^{31}$ Gray odmítá koncepci liberálního relativismu, který popírá existenci jakýchkoli univerzálních hodnot a tvrdí, že se liberálně orientované společnosti mohou vzdát svých univerzalistických nároků, aniž by změnily svůj charakter. Blíže např. Gray (2004, s. 34, 145).

${ }^{32}$ Gray (2004, s. 18).

${ }^{33}$ Je třeba dodat, že Williams dále rozpracovává své pojetí politických banalit jakožto nepolitických předobrazů s ohledem na formulování politických pojmů a je tedy ve své terminologii ve srovnání s Grayem mnohem důslednější. Nicméně domnívám se, že pro pochopení Grayova přístupu k univerzalistickým tendencím liberalismu, jakož i k jeho vlastní formě univerzalismu v podobě univerzálních forem dobra a zla je uvedené zjednodušené přirovnání daného Grayova pojetí k Williamsovým „univerzáliím“ dostačující. Blíže viz Hejduk (2011, s. 252). 
vivendi, jenž usiluje o ryze politický způsob nalezení podmínek pro koexistenci různých životních způsobů a konfliktních hodnot. ${ }^{34}$

\section{Modus vivendi}

Jak již bylo naznačeno výše, Grayova teorie modu vivendi vychází z názoru, že nelze nalézt žádný způsob života, jenž by byl ideální pro všechny lidské bytosti. Existuje totiž široká škála podob dobrého života, které jsou lidé schopni vést, a které zároveň nemůže obsáhnout jediná komunita či tradice. ${ }^{35}$ Modus vivendi se proto vyhýbá snaze o založení ideálního režimu, at' již liberálního či jiného, a namísto toho pouze hledá podmínky pro koexistenci různých životních způsobů. Pro Graye tedy modus vivendi představuje určitý soubor principů, jež bychom měli sledovat uvnitř jedné společnosti i mezi různými společnostmi navzájem, protože modus vivendi vychází z reálné podoby moderního pluralitního světa, když popisuje společenské uspořádání mezi lidmi zastávajícími konfliktní hodnoty a způsoby života. Vzhledem $\mathrm{k}$ tomu, že modus vivendi ze své podstaty odmítá nárok liberálních hodnot na univerzální autoritu, je nutně v rozporu s převažujícím univerzalistickým proudem liberalismu, avšak svým úsilím o hledání míru, souvisejícím s tradicí liberální tolerance, si tento politický ideál může dle autora nárokovat status obnovitele liberálního projektu. ${ }^{36}$

Modus vivendi podle Graye nicméně zajišstuje více než pouhou absenci války či rovnováhu moci, jelikož reflektuje, že ,nepotřebujeme společné hodnoty, abychom žili v míru. Potřebujeme společné instituce, v nichž by mohlo koexistovat mnoho podob života. “37 Obdobnou pozici, a sice že stát nemá preferovat žádnou podobu dobrého života, nýbrž má být vůči odlišným životním způsobům zcela neutrální, zastává v jistém smyslu i klasický liberalismus, nicméně Gray považuje jeho východiska za nedostatečná a usiluje o jejich prohloubení. V tomto ohledu se domnívám, že Gray se výše zmíněným tvrzením snaží poukázat na skutečnost, že ačkoliv klasický liberalismus hlásá opak, implicitně a nepřiznaně vždy již existenci určitých společných hodnot předpokládá. Vzhledem k tomu, že se klasický liberalismus rozvíjel v konkrétním historickém kontextu, směřovala jeho neutralita především vůči otázkám náboženského vyznání či etnického původu, avšak nezpochybňovala zažité principy individualisticky pojímaných tradic západní společnosti - těžko si lze např́íklad představit neutrální postoj klasických liberálů k polygamním společnostem či squatterství. Právě s ohledem na moderní pluralismus je tudíž dle Graye nutné tento klasický postoj reformulovat a vytvořit

\footnotetext{
${ }^{34}$ Tamtéž, s. 48.

${ }^{35}$ Tamtéž, s. 14.

${ }^{36}$ Tamtéž, s. 48.

${ }^{37}$ Tamtéž, s. 14.
} 
takové společné instituce, které skutečně umožní mírové soužití odlišných životních způsobů i v jejich aktuální a radikálnější podobě.

\section{Odkaz Hobbesova naturalismu}

Požadavkem na vytvoření a všeobecné uznání společných institucí, zajišt’ujících mírové soužití konfliktních hodnot a odlišných forem života, se Gray vymezuje vůči klasickému liberálnímu názoru, že konflikty hodnot či obecněji řečeno jakákoli skutečnost konfliktu jsou projevem nedokonalosti, o jejichž odstranění by měla každá morální či politická teorie usilovat. Autor naopak zdưrazňuje, že v etice i v politice je primárně nutné pochopit, proč se nelze konfliktu ve společnosti ani v životě jednotlivce vyhnout. Zde je patrná Grayova návaznost na Hobbese a jeho naturalistickou vizi prrirozeného mezilidského konfliktu vedoucího k válce všech proti všem, před níž mohou být lidské bytosti uchráněny pouze vytvořením suverénní autority zajišt'ující občanský mír. Ten je přitom víc než jen pouhou absencí občanské války, jelikož umožňuje vytvoření veřejných institucí, dle nichž mohou lidé navzdory svým odlišnostem navzájem koexistovat. ${ }^{38}$

Jak Gray zdůrazňuje, Hobbes v návaznosti na to postuluje nutnost založit stát na radikální toleranci vůči soukromému přesvědčení jedinců, ${ }^{39}$ nebot' lidé jsou dle něho od prrirozenosti egoisté, jednající vždy s ohledem na své vlastní zájmy, jež nejsou formovány kolektivně, ale vyvěrají právě z bytostně soukromých postojů. Tuto skutečnost přitom nelze prizmatem Hobbese nikdy - tedy ani ustavením jakékoli suverénní moci - zcela změnit. ${ }^{40}$ Jak Gray dále dodává, s ohledem na neměnnost lidské prìrozenosti Hobbes rovněž odmítá klasickou aristotelskou představu o nejvyšším dobru a přirozeném smyslu lidské existence, $\mathrm{k}$ jejichž realizaci člověk ve světě směřuje. Hobbes se totiž dle Graye naopak domnívá, že díky přirozenosti a vlivu okolností jsou lidé nuceni usilovat o dosažení stále se měnících předmětů své touhy, přičemž neexistuje žádné nejvyšší dobro, jehož by měli jedinci docílit, ale pouze nejvyšší zlo, které se snaží eliminovat. ${ }^{41}$

Gray přitom sdílí tyto Hobbesovy postřehy ohledně lidské přirozenosti, nebot' sám také tvrdí, že „lidé mají jakousi společnou přirozenost, která je ve svých potřebách v podstatě stálá,“42 přičemž jsou to právě různé lidské potřeby a odlišné formy dobra, které způsobují morální i politické konflikty. Krom toho výše uvedené postřehy dle

\footnotetext{
${ }^{38}$ Blíže viz Hobbes (2009, s. 89, 117).

${ }^{39}$ Gray (2000, s. 10).

${ }^{40}$ Blíže viz Hobbes (2009, s. 87-88).

${ }^{41}$ Gray (1993, s. 4).

${ }^{42}$ Gray (2004, s. 159).
} 
Graye rovněž potvrzují, že Hobbes je pro moderní politické myšlení zcela relevantní autor, nebot' ztělesňuje jednu ze dvou možných forem liberalismu strachu, dle níž není největším ohrožením společnosti a svobody jednotlivců stát se svými institucemi, ale anarchie, v níž je život jedinců řízen strachem z největšího zla, tj. z násilné smrti. Takto pojatý liberální projekt, usilující o mírové soužití a ochranu jedinců před zlem, je podle Graye v př́mém protikladu k druhému typu liberalismu strachu, jenž je charakterizován strachem ze státu, a tudíž i snahou o jeho maximální omezení. ${ }^{43}$ Přestože se tímto druhým zmíněným typem liberalismu strachu vyznačují téměř všechny současné liberální teorie, Gray přichází s názorem, že stát musí být po Hobbesově vzoru vnímán jako instituce sloužící k ochraně svých občanů před zlem, ${ }^{44}$ nikoli - jak se domnívají moderní liberální myslitelé - jako nástroj umožňující „transcendentální vyvození západních institucí jakožto jediných legitimních forem vlády“. ${ }^{45}$ Domnívám se, že Gray tímto tvrzením opět poukazuje na nutnost zachování bytostného politična, jež odkazuje k primární potřebě přežití a vytvoření mírové spolupráce mezi lidmi, respektive ke stále naléhavé politické otázce po legitimizaci státu. Takto chápané politično pak navíc stojí $\mathrm{v}$ přímém protikladu $\mathrm{k}$ abstraktním teoriím, vytvářejícím univerzálně platné instituce a mravní ideály bez ohledu na proměnlivou dějinnou situaci. Kromě toho zdůrazněním základního úkolu státu, tj. ochrany jedinců před zlem Gray nejenom že odkazuje k Hobbesovi jakožto mysliteli hodnému následování, ale také odhaluje spř́zněnost své politické teorie modu vivendi právě s aktuálním proudem liberalismu strachu, jenž na Hobbesovu teorii rovněž navazuje. ${ }^{46}$

\section{Hodnotový pluralismus}

Při snaze o pochopení Grayovy politické teorie modu vivendi je nezbytné zaměřit se rovněž na objasnění etické koncepce hodnotového pluralismu, jež tvoří samotné jádro autorova pojetí modu vivendi. Díky tomu, že klíčové atributy moderní společnosti jako migrace a masová komunikace odbouraly tradiční monokulturní charakter jednotlivých států a rozšíríily rozdílné životní způsoby např́íc společným prostorem, se dle Graye

\footnotetext{
${ }^{43}$ Gray (2000, s. 10-11).
}

${ }^{44} \mathrm{~V}$ tomto ohledu je nutné zdůraznit, že Gray chápe zlo, před nímž má stát jedince chránit, po Hobbesově vzoru ve značně minimalistické formě, tj. například jako násilnou smrt, mučení, věznění, bídu a podobně, tedy jako univerzální formy zla, na nichž se všichni lidé shodnou.

${ }^{45}$ Gray (2000, s. 12).

${ }^{46}$ Zde je třeba podotknout, že ačkoli Gray reflektuje, že Hobbes ve své politické teorii vychází z liberálního pojetí společnosti, avšak řešení odlišných lidských zájmů a morálky spatřuje v ustavení absolutního suveréna, který ze své podstaty politično odbourává, pro účely své vlastní teorie modu vivendi pracuje pouze s Hobbesovým původním předpokladem minimalistické definice státu bez ohledu na její vyústění. 
konflikty hodnot, potažmo pluralismus jako takový staly naším historickým osudem. ${ }^{47}$ Jak Gray tvrdí, hodnotový pluralismus ztělesňuje přesvědčení, že existuje mnoho druhů dobrého života, přičemž některé z nich nelze hodnotově poměřovat, poněvadž nejsou ani lepší, ani horší či stejné, nýbrž jsou nesouměřitelně hodnotné. Hodnotový pluralismus si přitom klade za cíl věrnost etickému životu ${ }^{48}$ - projevuje-li se tedy lidské dobro konkurenčními životními způsoby, je třeba to akceptovat, nebot' etika je dle Graye založena na empirickém zkoumání, nikoli na a priori daných pravdách. ${ }^{49}$ Vzhledem k tomu, že Gray tvrdí, že hodnotu právě jen „některých“ životních způsobů nelze srovnávat, je evidentní, že autor předpokládá rovněž existenci určitých špatných životních způsobů. Otázkou ovšem zůstává, na základě jakého kritéria je možné rozhodnut, které životní způsoby jsou ty dobré a které nikoli. Domnívám se, že Gray v tomto ohledu neposkytuje uspokojivou odpověd', nebot' jak bude ukázáno níže, odkazem na existenci univerzálních forem dobra a zla se autor nedokáže přesvědčivě vyrovnat s námitkami, které se týkají jeho nedostatečného vymezení dobrého a zlého.

V této souvislosti Gray přichází s tvrzením, že

„hodnotový pluralismus má blíže k etickým teoriím, které potvrzují možnost morálního vědění, než ke známým typům etického skepticismu, subjektivismu či relativismu“. 50

Proto je také dle Graye hodnotový pluralismus oprávněn upřednostňovat některé formy dobra před jinými, ${ }^{51}$ jakož i odmítnout autoritu jediné pravdy. Jestliže totiž platí, že dobro je pluralitní a jako takové nemůže být stejné pro každého, je zřejmé, že v něm obsažené konflikty mají více než jen jedno správné řešení. Jeden životní způsob tudíž může konkrétní dobra a ctnosti uznávat, zatímco druhý způsob života je zcela zavrhuje, a ačkoliv se taková situace jeví jako značný paradox, prizmatem hodnotového pluralismu mohou mít pravdu oba životní způsoby současně. Gray v této souvislosti podotýká, že pokud se moderní liberální myšlení odvolává na pluralismus, míní jím převážně rozmanitost osobních etických přesvědčení. Avšak ten druh pluralismu, s nímž operuje Gray a z něhož pochází konflikty hodnot utvářející politické myšlení, není spjat

${ }^{47}$ Gray (2004, s. 51).

${ }^{48}$ Slovní spojení „,vernost etickému životu“ lze v rámci Grayovy teorie chápat jako reflexi a následné přijetí skutečnosti moderního pluralismu a s ním souvisejícího neustálého konfliktu hodnot a životních způsobů. Gray přitom onou „,věrností“ zdůrazňuje nutnost orientovat se v proměnlivých dějinných situacích na základě lidské zkušenosti, nikoli odvoláváním se na abstraktní morální teorie.

${ }^{49}$ Gray (2004, s. 52).

${ }^{50}$ Tamtéž, s. 15.

${ }^{51}$ Gray se tímto tvrzením snaží vyhnout především ztotožnění hodnotového pluralismu $\mathrm{s}$ relativismem, což je pro něho také jednou z primárních motivací pro stanovení univerzálních forem dobra a zla. 
s odlišnými názory jednotlivců, nýbrž s protichůdnými požadavky jednotlivých životních způsobů. ${ }^{52}$ To je v souvislosti s Grayovou politickou teorií zásadní tvrzení, nebot' tím, že jeho koncepce odmítá moralizující tendence liberálního univerzalismu, snaží se nutně nahlížet i hodnotový pluralismus nikoli pouze v rovině individuálních zájmů jednotlivců, nýbrž spíše politickou optikou zahrnující komplexní životní způsoby, jež tito jednotlivci vedou a jež v konci utváří politické uspořádání modu vivendi.

Problematika hodnotového pluralismu a jeho politických implikací přivádí Graye k myšlenkovému odkazu Berlinovy filosofie, nebot' Berlin stejně jako Gray odmítá připustit existenci nejvyššího dobra či jakékoli jiné univerzálně platné koncepce lidského života - oba autoři přitom tvrdí, že vzhledem k této skutečnosti jsou volby, které musíme mezi nesouměřitelnými hodnotami činit, často radikální a tragické. Tím ovšem ani jeden z myslitelů nechce říci, že nesouměřitelnost dober či nemožnost dospět k racionální shodě ohledně nejlepšího životního způsobu potvrzují tezi o nedokonalosti lidského života, nýbrž že samotná idea dokonalosti postrádá smysl. ${ }^{53}$ Tím se odhaluje i záměr Grayovy interpretace Berlinova hodnotového pluralismu, jenž spočívá ve snaze dokázat, že fakt pluralismu vede kodmítnutí dosud dominantního liberálního univerzalismu, jenž je bezděčně zatížen konflikty hodnot, na něž však sám nedokáže poskytnout uspokojivou odpověd'.

V základu Grayova hodnotového pluralismu tedy stojí konflikty hodnot, které přímo souvisí s existencí člověka, nebot' pro společnost dle autora není nejdůležitější existence protichůdných přesvědčení o dobrém životě ze strany jednotlivců, nýbrž skutečnost, že lidské potřeby vytváří konfliktní požadavky. Život makléře na burze a mnicha v klášteře se proto nedají skloubit, jak Gray píše, aniž by nedošlo ke ztrátě některé ze ctností, kterou se daný životní způsob vyznačuje. ${ }^{54}$ Touto optikou by totiž makléř na burze, usilující o přijetí mnichovy askeze, musel nutně rezignovat na vlastní pozitivní hodnoty vysoké cílevědomosti a pracovní morálky, naopak mnich by byl akceptací makléřova materialistického postoje nucen odmítnout svou vyrovnanou smířenost a altruismus. To podle Graye dokládá, že ideální lidské životy jsou vzájemně neslučitelné a že napětí mezi jejich požadavky je obecným zdrojem morálního konfliktu. ${ }^{55}$

\footnotetext{
${ }^{52}$ Gray (2004, s. 22).

${ }^{53}$ Gray (1993, s. 65).

${ }^{54}$ Gray (2004, s. 19).

${ }^{55}$ Tamtéž, s. 17.
} 


\section{Univerzální minimum}

Navzdory faktu nesouměřitelnosti hodnot a životních způsobů můžeme mít dle Graye dobré důvody pro upřednostňování některých forem dobra na úkor jiných, nebot' ne všechny životní způsoby lidem umožňují žít št’astně. Jak autor píše: „existují totiž univerzální lidská dobra a zla,“56 na jejichž základě lze stanovit určité „,univerzální minimum““57 genericky lidských hodnot, jež jsou potřebné pro jakýkoli životní způsob, jestliže má být považován za dobrý. K určení univerzálního minima přitom Gray dospívá negativní cestou, respektive prostřednictvím univerzálních forem zla, jež brání vést lidem jakýkoli hodnotný život. Grayův hodnotový pluralismus lze proto označit jako určitou diskriminující morální pozici, jelikož identifikuje některé způsoby života jako špatné, aniž by poskytl přesná kritéria pro jejich vymezení, př́ípadně blíže určil, které konkrétní životní způsoby jsou dobré a proč tomu tak je. ${ }^{58}$ Tomuto názoru ostatně odpovídá i Grayova vágní definice univerzálních hodnot, o nichž tvrdí, že:

„mají co do činění s překážkami stojícími v cestě jakémukoli druhu cenného

lidského života, a jsou nejlépe vyjádřeny v podmínkách, které nejpříměji ohrožují vyhlídku takového života.“59

Ačkoli tedy Gray neposkytuje přímý výčet univerzálních forem zla, hovoří například o násilné smrti, mučení, věznění, pronásledování, ponižování, ohrožování genocidou, bídě, nevyléčitelných chorobách a mnohých dalších formách zla, jejichž uznání za univerzální formy zla je možné vzhledem k tomu, že z nich vyplývající důsledky a zkušenosti jsou totožné pro všechny lidské bytosti bez ohledu na jejich etická přesvědčení. ${ }^{60}$ Zde je ovšem třeba podotknout, že Gray v souvislosti s uznáním univerzálních forem dobra i zla, potažmo určité objektivity hodnot neuniká jistým epistemologickým problémům, souvisejícím s faktem, že univerzální hodnoty nám nejsou dány a priori, tudíž je nemůžeme odvodit pouze z našeho rozumu. Gray se proto dle svých slov uchyluje k tzv. „internímu realismu“61 neboli k názoru, že lidé mají společnou přirozenost, která je ve svých potřebách stálá a která tvoří základ objektivních hodnot, respektive univerzálních forem dobra a zla. Proto se také dle Graye mýlí skeptici, relativisté i subjektivisté, když se domnívají, že změna v našich morálních

\footnotetext{
${ }^{56}$ Tamtéž.

${ }^{57}$ Termín „univerzální minimum“ Gray na žádném místě přímo neuvádí, nicméně domnívám se, že pro označení autorem vymezených minimálních standardů či podmínek štastného životního způsobu jej lze oprávněně použít.

${ }^{58}$ Jones (2007, s. 88).

${ }^{59}$ Gray (2007, s. 216).

${ }^{60}$ Gray (2004, s. 89).

${ }^{61}$ Blíže viz Gray (1993, s. 297).
} 
přesvědčeních může vést k odlišným soudům o univerzálních formách zla, poněvadž nereflektují hobbesovskou pravdu, že ,změníme-li svoje přesvědčení o sobě, nezměníme tím ještě své potřeby“ “. ${ }^{62}$ Gray tak zdůrazňuje, že bez ohledu na to, jakou abstraktní morální teorii budeme považovat za správnou, v každodenní realitě se budeme vždy nejprve potýkat s nutností zajistit naše primární potřeby jako např́íklad prevenci ohrožení vlastní existence. Teprve tehdy, kdy budou tyto potřeby zabezpečeny - což je ovšem úkolem politiky, potažmo státu - je možné zabývat se dalšími politickými i morálními otázkami.

Gray prritom zdůrazňuje, že hodnoty lze považovat za objektivní do té míry, nakolik tyto vychází z objektivních individuálních potřeb a zájmů, jež jsou jistým způsobem poznatelné rozumem. Toto tvrzení však Gray dále problematizuje, když postuluje, že povaha lidských bytostí je společnou prrirozeností determinována jen částečně, nebot' určitým dílem je dána jejich vlastní sebe-definicí. Objektivní hodnoty jsou proto také zčásti určené společnou přirozeností a zčásti veřejnými způsoby života, které pro sebe lidé vytvořili. Ačkoli se Gray ve své teorii v mnoha ohledech odvolává na lidskou zkušenost, je třeba zdůraznit, že Gray reflektuje možné odlišnosti v interpretaci této zkušenosti ze strany jednotlivých lidí. Proto také v souvislosti s uznáním existence univerzálního minima považuje za nutné uvést, že univerzální či objektivní hodnoty jsou poznatelné za předpokladu vyvážené kombinace zkušenosti a reflexe. ${ }^{63}$ Jak ovšem upozorňuje John Horton, Grayova doktrína hodnotového pluralismu je v podstatě meta-etickou teorií, která ponechává otázku vymezení skutečně univerzálně hodnotných způsobů života otevřenou. Horton $\mathrm{v}$ tomto směru přichází $\mathrm{s}$ názorem, že Grayovo spoléhání se na zkušenost poskytuje pouze omezenou pomoc, přičemž vymezení univerzálního minima navíc naznačuje, že teoretik hodnotového pluralismu si nárokuje privilegovanou pozici v poskytnutí odpovědi, jaké hodnoty lze považovat za objektivní. Tento nárok by ovšem dle Hortona mohl být chápán jako teoretická arogance srovnatelná s liberálními univerzalisty, kterým se Gray snaží oponovat. $^{64}$

Dle mého soudu je však Grayovo stanovisko v otázce univerzálního minima spíše než vyjádřením určité teoretické arogance důkazem autorova nedostatečného argumentačního postupu. Domnívám se totiž, že Gray svým stanovením univerzálních forem dobra a zla jednak neposkytuje uspokojivé kritérium pro rozlišení dobrého a zlého, jednak dostatečně neobjasňuje záměr své politické teorie. S ohledem na to, jak Gray hovoří o univerzálních formách dobra a zla, je oprávněné klást si otázku, na základě jakého kritéria je bez jakékoli bližší specifikace vůbec možné rozhodnout, které

\footnotetext{
${ }^{62}$ Gray (2004, s. 89).

${ }^{63}$ Gray (1993, s. 297).

${ }^{64}$ Horton (2007, s. 48).
} 
konkrétní jednání lze chápat například jako univerzální formu ponižování - tak jako může jedna žena oceňovat zaplacení účtu v restauraci jako důkaz lásky a péče svého partnera, může jiná žena chápat stejné jednání jako znevažování její důstojnosti a tedy i určitou formu ponižování. Dle mého názoru ovšem Gray svou definicí univerzálního minima nezamýšlí rozlišovat takovéto nuance v lidském jednání, ač jsou samožrejmě pro život jedinců důležité, nýbrž usiluje o popsání mnohem základnějších forem dobra a zla, které v podstatě ovlivňují přežití člověka ve společnosti. Zajištění těchto univerzálních dober spolu s eliminací univerzálních zel je přitom úkolem každého legitimního státu a nutnou podmínkou pro rozvíjení veškerých dalších dober. Přestože budeme předpokládat, že Gray chápe univerzální formy dobra a zla v těchto minimalistických intencích, nevyhneme se tak požadavku po preciznějším vymezení jak univerzálního minima, tak i samotného účelu Grayovy teorie modu vivendi.

Gray v této souvislosti zdůrazňuje, že svým tvrzením ohledně existence univerzálních forem dobra a zla $\mathrm{v}$ žádném případě nepodporuje myšlenku jedné univerzální morálky, kterou hájí většina liberálních myslitelů. Univerzální hodnoty jsou totiž dle Graye slučitelné s mnoha morálkami, včetně té liberální. ${ }^{65} \mathrm{~V}$ souvislosti s uznáním určitého univerzálního minima, jakož i práva na odmítnutí jakékoli univerzální morálky Gray zdůrazňuje, že neexistuje žádný režim, který by mohl být na základě racionálních důvodů vnucen všem typům společnosti, nebot': „žádný režim nemůže skutečně tvrdit, že ztělesňuje to nejlepší urovnání konfliktů univerzálních hodnot. “66 $Z$ toho důvodu také podle Graye nemá smysl vést spory o to, jaký režim je tím nejlepším, nebot' existuje mnoho dobrých způsobů života, jimiž mohou lidé prosperovat.

Zdůrazněním existence univerzálních lidských hodnot Gray dospívá nejenom k potvrzení platnosti univerzálních lidských práv, ale také $\mathrm{k}$ důležité otázce po legitimitě konkrétního režimu. Jak autor píše, hlavní úlohou lidských práv je chránit jedince před univerzálními formami zla, přičemž je třeba mít na paměti, že tak jako se podle specifických okolností a lidských zájmů proměňují konkrétní projevy univerzálních forem zla, dochází i k modifikaci univerzálních lidských práv. Ta tudíž nepředstavují neměnná morální absolutna, ale konvence, jejichž obsahy se mohou dle konkrétního kontextu v průběhu času značně lišit a dokonce se dostávat do vzájemných konfliktů. To je také dle Graye důvod, proč nelze stanovit žádný definitivní a neměnný seznam lidských práv. Gray nicméně tvrdí, že stejně jako v případě univerzálního minima i v případě univerzálních lidských práv platí, že existují taková práva, která musí dodržovat všechny politické systémy, aby bylo možné tyto režimy v současných podmínkách považovat za legitimní. Proto je také nutné na lidská práva pohlížet ,jako

\footnotetext{
${ }^{65}$ Horton (2007, s. 48).

${ }^{66}$ Gray (2004, s. 91).
} 
na ztělesnění minimálních standardů politické legitimity, které jsou použitelné pro všechny režimy“. ${ }^{67}$

Jak Gray dodává, i když není vzhledem k dějinné proměnlivosti možné specifikovat veškeré podmínky legitimity, je zřejmé, že režim lze označit za nelegitimní v té míře, v jaké je jeho moc závislá na systematickém poškozování široké škály lidských zájmů, znemožňujícím vést jakýkoli druh hodnotného života. Ačkoli tedy dle Graye existují minimální standardy slušnosti a legitimity aplikovatelné na všechny současné režimy, nejsou těmito standardy pouze očividné liberální hodnoty. To bylo podle Graye patrné v případě Castrova režimu na Kubě, potlačujícího životně důležité svobody jako například liberální svobodu vyjadřování, ale zároveň hájícího zájmy lidí na okraji společnosti lépe než některé vyspělé země, nebot' například kubánský zdravotnický systém a školství fungovaly pro chudé občany efektivněji než u mnohých znevýhodněných Američanů. Na Kubě se tak dostává do střetu hodnota osobní svobody se starostí o blahobyt lidí na okraji společnosti, nicméně obě tyto hodnoty lze označit za univerzální a nezbytné pro jakýkoli dobrý životní způsob. Na základě toho Gray vyvozuje, že univerzální lidská práva mohou být ctěna a vynucována jak liberálními, tak i neliberálními režimy, přičemž „,chápeme-li je takto, netvoří univerzální lidská práva žádnou překážku modu vivendi rozdílných režimů, nýbrž jeho podmínku“ “. ${ }^{6}$

Gray přitom ve své teorii usiluje právě a „pouze“ o určení těchto minimálních standardů legitimity, jež vycházejí z univerzálních forem zla a jako takové zaručují splnění základního požadavku legitimizace na zabezpečení jedinců před zlem. Teprve ve chvíli, kdy bude tento požadavek splněn, lze zvažovat další - pro lidské bytosti důležité, nikoli však primární - záležitosti jako např́klad rovnost příležitostí. Gray se dle mého názoru tímto minimalistickým cílem své teorie řadí $\mathrm{k}$ Hobbesovi a $\mathrm{k}$ představitelům liberalismu strachu, přičemž jeho východiskem je právě skutečnost moderního pluralismu, na jejímž základě nelze vytvářet univerzálně platné politické či morální teorie.

\section{Etický rozměr modu vivendi}

Zaměříme-li se nyní na posouzení etického rozměru autorovy politické koncepce, je namístě připomenout již zmíněný Grayův postulát, že ,,modus vivendi je projektem politickým, nikoliv morálním ideálem“, ${ }^{69}$ jenž na první pohled ostř̌e kontrastuje s jiným Grayovým tvrzením, že „stejně jako každá jiná politická filosofie, i modus vivendi

\footnotetext{
${ }^{67}$ Tamtéž, s. 142.

${ }^{68}$ Tamtéž, s. 153.

${ }^{69}$ Tamtéž, s. 38.
} 
formuluje názor na dobro.“70 Tento názor však v případě Grayovy politické teorie nelze ztotožňovat s určitým normativním ideálem zakládajícím univerzální morálku, nebot' jak jsme mohli pozorovat výše - Grayův náhled na dobro spočívá v rámci modu vivendi ve faktu hodnotového pluralismu, který ze své podstaty vylučuje jakékoli univerzalistické tendence činící si nárok na vyřešení morálních dilemat. $\mathrm{S}$ ohledem na četná nejednoznačná tvrzení, jakož i na množství problematických rysů Grayovy koncepce modu vivendi, není nicméně překvapujícím zjištěním, že Gray čelí řadě námitek týkajících se nedostatečného či zcela chybějícího etického obsahu modu vivendi. $\mathrm{Z}$ těchto námitek lze jmenovat např́íklad právě autorovo pojetí hodnotového pluralismu, jež sice na jedné straně zdůrazňuje nesouměřitelnost hodnot a životních způsobů, znemožňující stanovit určité nejvyšší dobro, na druhé straně však připouští existenci - byt' Grayem poněkud vágně formulovaného - univerzálního minima. Gray tedy sám trvá na existenci určitých univerzálně platných lidských dober a zel, které musí modus vivendi reflektovat, a to i navzdory tomu, že toto univerzální minimum přímo neposkytuje konkrétní soubor politických pravidel.

Domnívám se, že Grayova politická teorie považuje za svou hlavní přednost právě určitý minimalismus, spočívající prredevším v odmítání jakýchkoli ideologických či morálních aspirací. To je zřejmé i na Grayově kritice univerzalistického pojetí liberalismu, který ve většině případů odvozuje politiku od morálky, čímž vytváří pouze abstraktní teorii, jež však bud' není schopna reflektovat pluralitní podmínky moderního světa, nebo je cíleně přehlíží v zájmu zachování pouhé teorie činící si nárok na definitivní vyř̌šení morálních i politických konfliktů. Politická teorie je podle Graye nicméně založená na pluralitních názorech na dobro a jako taková je nutně konfliktní. Snahou o potlačení těchto bytostných konfliktů pak dle Graye dochází kjisté depolitizaci, potažmo $\mathrm{k}$ vytlačení politična z liberální teorie. Předpokládám, že právě před tímto odbouráním politična $v$ rámci univerzalistického proudu liberalismu Gray varuje, když zdůrazňuje vyčerpanost liberalismu jakožto politické teorie. ${ }^{71}$

Pro lepší pochopení Grayova odmítnutí teorie v zájmu zachování politična, jakož i jeho kritického př́istupu k morálnímu založení politiky považuji za vhodné využít Williamsovo rozlišení dvou modelů politické teorie, zákonodárného a strukturálního, jež představují formy tzv. politického moralismu, preferujícího morálku před političnem. Jak Williams vysvětluje, ačkoli se uvedené verze politické teorie značně liší, obě se shodují v tom, že jsou v podstatě aplikacemi morálních postulátů, nebot'

\footnotetext{
${ }^{70}$ Tamtéž.

${ }^{71}$ Blíže viz Gray (2007, s. 224).
} 
„V zákonodárném modelu je politika ... nástrojem morálky, ve strukturálním modelu morálka omezuje ... politiku v tom, co může právoplatně činit." ${ }^{\text {72 }}$

Zákonodárný model politické teorie přitom dle Williamse reprezentují především představitelé utilitarismu, strukturální model pak např́klad Rawls. ${ }^{73}$

Rawlsovu politickou filosofii ostatně využívá i Gray - byt' v této souvislosti nerozlišuje Williamsem zavedenou dichotomii zákonodárných a strukturálních modelů - jako typický př́klad univerzalistického pojetí liberalismu, zdůrazňujícího primát morálky a následné již zmíněné vytlačení politična. Nutno nicméně dodat, že Rawls sám připouští, že jeho politická teorie je zároveň i teorií morální, nebot' jejím záměrem je zformování ideálních institucí, které budou brát v potaz morální intuice jednotlivců. Tím tyto instituce zároveň zprostředkují vytvoření určitého neutrálního prostředí morální teorie, v jejímž rámci lze odstranit konflikty hodnot. ${ }^{74}$ Domnívám se tedy, že i když Rawls pracuje s faktem pluralismu, prizmatem Grayovy teorie chybně předpokládá, že konflikty hodnot můžeme určitým způsobem eliminovat. V tom spočívá také zásadní odlišnost Grayovy politické koncepce od Rawlsova pojetí liberalismu - byt' oba tvrdí, že režim není legitimní na základě toho, zda jsou jeho principy ve shodě s určitou koncepcí dobra, Grayův modus vivendi odmítá i to, že by zkouškou legitimity jakéhokoli režimu mohla být jeho konformita s teorií spravedlnosti. Dle Graye totiž Rawlsova teorie spravedlnosti selhává, jelikož se její autor mylně domnívá, že pro naplnění principu spravedlnosti lze garantovat každému určité základní svobody, které spolu nebudou ve vzájemném konfliktu, budou-li vhodným způsobem přizpůsobeny a regulovány. ${ }^{75}$

To však Gray odmítá, nebot' tvrdí, že samotné základní svobody jsou přímým dějištěm konfliktů hodnot, tudíž je nelze začlenit do jednoho harmonického schématu. Skutečnost, že konflikty základních svobod ovlivňují názory lidských bytostí na spravedlnost, Rawls ovšem dle Graye nereflektuje, jelikož cílem jeho teorie je formulovat principy spravedlnosti, s nimiž musí souhlasit každý racionální jedinec bez ohledu na svou koncepci dobra, což vede k vytvoření liberální právní filosofie, upřednostňující spravedlnost před všemi ostatními formami dobra. Oproti tomu Grayův modus vivendi, vycházející z Hobbese, si nečiní nárok na postulování jakýchkoli právních principů, nýbrž posuzuje schopnost jednotlivých režimů sjednávat kompromisy mezi odlišnými představami o dobru. Jak Gray píše

\footnotetext{
${ }^{72}$ Williams (2011, s. 28).

${ }^{73}$ Tamtéž, s. 27.

${ }^{74}$ Rawls (1996, s. 11).

${ }^{75}$ Tamtéž, s. 175-176.
} 
„výsledkem je liberální filosofie, podle níž má dobro přednost před právem, podle níž však žádný názor na dobro nemá přednost před všemi ostatními.“76

S ohledem na to eliminace konfliktních hodnot dle Graye nejenom že není možná, nýbrž ani žádoucí, poněvadž pojem pluralitní $\mathrm{v}$ jeho pojetí znamená inherentně konfliktní a zároveň tedy nutně politické. Jestliže tak spolu s Rawlsem předpokládáme možnost definitivního odstranění etických a politických konfliktů, troufám si tvrdit, že podle Graye tím připouštíme i odbourání bytostného politična a jeho chápání jako pouhé aplikace morální teorie, jež však postrádá jakékoli praktické opodstatnění.

Vrátíme-li se zpět k Williamsovi, je vhodné poukázat na skutečnost, že kromě politického moralismu hovoří tento autor rovněž o politickém realismu. Ten na rozdíl od prvního jmenovaného skýtá ve Williamsově pojetí mnohem širší prostor pro ryze politický způsob uvažování, jelikož odmítá existenci zásadního vztahu mezi morálkou a politikou, třebaže připouští, ,že může docházet $\mathrm{k}$ místním aplikacím morálních idejí v politice. “77 Williams přitom v souvislosti s realističtějším přístupem $\mathrm{k}$ liberalismu zdůrazňuje jako klíčovou tzv. první politickou otázku, kterou chápe v hobbesovském smyslu jako zajištění ochrany, pořádku, bezpečí, důvěry a podmínek pro kooperaci a která dle něho tvoří základní požadavek legitimizace. ${ }^{78}$ Tím se dle mého názoru odkrývá výrazná podobnost Grayovy teorie modu vivendi s př́stupem politického realismu, který tematizuje právě Williams. Stejně jako Williamsův politický realismus i Grayův modus vivendi totiž nejenom že odmítá přílišné morální zatížení liberální teorie, ale v návaznosti na Hobbese shodně usiluje i o vytyčení minimálních požadavků legitimity (jež jsou v Grayově případě ztělesněny univerzálním minimem), umožňujících odlišit legitimní stát od nelegitimního. Kromě toho Williamsova identifikace dvou protichůdných přístupů, politického moralismu a politického realismu, formulovaných na základě již uvedeného vztahu morálky a politiky, připomíná do značné míry Grayovo rozlišení mezi univerzalistickým proudem liberalismu a jím předkládaným alternativním ideálem modu vivendi. Přestože Gray neformuluje zpo̊sob, jakým k tomuto rozdílu dospívá, natolik explicitně jako Williams, domnívám se, že i pro něho spočívá primární motivace v zavržení moralizujících a univerzalistických tendencí převažujícího pojetí liberalismu, jež se snaží o stanovení ideálních a neměnných pravidel lidského soužití. Taková pravidla jsou totiž dle Graye statická a postrádají jakýkoli smysl, nebot' v podmínkách moderního pluralismu nedokáží reflektovat často protichůdné a proměňující se lidské zájmy a hodnoty. $\mathrm{Z}$ toho důvodu se Gray přiklání $\mathrm{k}$ minimalističtěji formulované teorii modu vivendi, která

\footnotetext{
${ }^{76}$ Tamtéž, s. 177.

${ }^{77}$ Williams (2011, s. 36).

${ }^{78}$ Tamtéž, s. 30-31.
} 
namísto utváření nadčasových ideálů prosazuje mnohem političtější způsob uvažování o společnosti, reflektující historický kontext a pluralitní názory na dobro.

V podobném duchu uzavírá diskusi ohledně etického rozměru Grayova modu vivendi i John Horton, když poukazuje na tvrzení Glena Neweyho, že současnou liberální teorii lze charakterizovat jako formu redukcionismu, v níž je údajný subjekt politiky transformován do jiné sféry, a to obvykle do roviny etiky. Dle Hortona je ovšem toto pojetí problematické, poněvadž politika nemůže být chápána jednoduše jako odnož etiky - předpokládat, že správný způsob řešení problému sociální spravedlnosti tkví v představě hypotetické dohody ustavené za ideálních podmínek vzájemné rovnosti a svobody, znamená abstrahovat z tohoto politického problému to, co je na něm ryze politické. Politika totiž musí konfrontovat nejenom existenci odlišných koncepcí sociální spravedlnosti, kolizi různých etik a zájmů, ale také limity toho, co je možné prakticky činit v konkrétní situaci. Horton přitom upozorňuje, že teorie modu vivendi se snaží vzít v úvahu závažnost těchto všudypřítomných a nutných rysů politiky, což je její pravou devízou. ${ }^{79}$ Nicméně i tak je třeba přiznat, že Grayův modus vivendi skýtá řadu nedostatků, jež jsou dány především silným omezením role jakékoli normativní teorie. S ohledem na toto omezení bude politické zřízení založené na modu vivendi vždy podmíněno historickými či kulturními okolnostmi, a přestože nebude díky Grayem zdůrazňovanému univerzálnímu minimu a ideálu tolerance zcela zbaveno obsahu, nebude moci stanovit definitivní soubor principů a institucí, o něž by mělo politické jednání usilovat. ${ }^{80}$

Na základě uvedených postřehů, jakož i srovnáním určitých Williamsových postulátů s Grayovou politickou filosofií je možné dospět k závěru, že Grayova teorie modu vivendi nepředkládá žádnou vyčerpávající koncepci morálky, jež by si nárokovala univerzální autoritu a určovala tak i konkrétní politické zásady. Modus vivendi naopak usiluje o zachování pravého politična se všemi jeho konfliktními a proměnlivými rysy na úkor pouhé teorie, přičemž jeho primárním úsilím je hledání podmínek mírového soužití v moderním pluralitním světě. To ovšem neznamená, že by Grayova politická teorie postrádala jakýkoli etický rozměr. At' už je totiž Grayovo vymezení univerzálního minima jakkoli vágní či sporné, představuje nejenom klíčový důkaz autorova vnímání vlivu etických problémů na utváření a fungování veškerých politických teorií, ale i pokus o vyřešení mnohých obtíží modu vivendi spjatých zejména s absencí specifické koncepce nejvyššího dobra a se zdánlivým relativismem. Nutno dodat, že Gray svým formulováním univerzálního minima v podstatě připouští určitý univerzalismus, nicméně toto minimum univerzálních forem dobra a zla chápe jako výsledek historické a empirické metody. To mu umožňuje i nadále odlišovat svou vlastní teorii od

\footnotetext{
${ }^{79}$ Horton (2007, s. 53-54).

${ }^{80}$ Tamtéž, s. 51.
} 
převažujícího univerzalistického proudu liberalismu, který na rozdíl od Grayova modu vivendi odvozuje objektivitu svých principů z abstraktní morální teorie. Grayův př́stup naproti tomu ukotvuje objektivně existující minimum v realistické, potažmo politické teorii, nebot' autor z něho vyvozuje pouze minimální standardy politické legitimity, $\mathrm{k}$ jejichž přizpůsobení má politika směřovat. Charakter těchto standardů legitimity je totiž ryze procedurální, jelikož - jak již bylo naznačeno výše - Gray v jejich souvislosti hovoří čistě o potenciálu pro zabezpečení míru, uspokojení základních životních potřeb či pro zajištění reprezentativní vlády i možnosti jejího odvolání, což naznačuje, že Gray v jejich případě neusiluje o normativní vymezení pevně daných hodnot, nýbrž o stanovení politických postupů, jež musejí být respektovány, aby bylo možné daný režim označit za legitimní. Je ovšem zřejmé, že na základě takto procedurálně pojatých atributů nelze vytvořit komplexní morální teorii, přičemž Gray si dle mého soudu takové nároky ani nečiní.

\section{Grayova ideologická příslušnost}

Vezmeme-li v potaz výše uvedené postřehy ohledně Grayovy politické teorie modu vivendi a jejího etického rozměru, nezbývá než v souladu se stanovenými cíli studie posoudit, zda lze Grayovu teorii chápat v intencích liberalismu, či zda autorova koncepce představuje vůči liberálnímu myšlení určitou alternativu. V této souvislosti je třeba podotknout, že pro zhodnocení Grayova možného zařazení do tradice liberálního myšlení, respektive pro jeho eventuální vyloučení není př́liš nápomocný ani autorův explicitní postoj, nebot' Gray sám sebe označuje poměrně vágním způsobem za myslitele pracujícího v rámci liberální tradice i proti ní. ${ }^{81}$ Soudím, že Grayovo přesvědčení o zařaditelnosti vlastní teorie „do prostoru“ mezi stoupence a odpůrce liberalismu vychází primárně ze zpo̊sobu, jakým autor dospívá k formulování vlastní teorie modu vivendi, jenž je založen na soustavné kritice univerzalistického liberalismu, a jenž tudíž může být chápán jako autorova snaha vymezit se proti liberální tradici jako takové. Jak totiž Gray postuluje, všechny typy liberalismu, mající své těžiště $\mathrm{v}$ univerzalistickém přístupu $\mathrm{k}$ vytvoření ideálního režimu a morálky, jsou verzemi osvícenského projektu, přičemž ve chvíli, kdy namísto nich upřednostníme ideál modu vivendi, jenž tento zdůrazněný univerzalismus odmítá, vzdáme se tím nutně i samotného liberalismu. ${ }^{82}$ Osobně se nicméně domnívám, že Grayova snaha o odhalení teoretických nedostatků liberálního myšlení a o jejich možnou nápravu upřednostněním vhodnějšího liberalismu mírového soužití, jenž získává svou konečnou podobu v Grayově teorii modu vivendi, naznačuje, že Gray v podstatě pracuje výlučně uvnitř liberální tradice. Budeme-li totiž liberalismus chápat v tradičním slova smyslu jako doktrínu založenou

${ }^{81}$ Tamtéž, s. 43.

${ }^{82}$ Gray (2004, s. 179). 
na myšlence nezcizitelných lidských práv a minimálního státu, který nezasahuje do soukromé sféry individuálně pojímaných občanů a jehož politická moc nemá za úkol realizovat hodnotové cíle, nýbrž umožnit jednotlivcům jejich maximální svébytný rozvoj, ${ }^{83}$ je evidentní, že Gray svou formulací teorie modu vivendi tradici liberalismu neopouští, nýbrž usiluje pouze o její zevrubnou revizi.

Nutno nicméně dodat, že otázku, zda lze Graye řadit mezi liberální myslitele či nikoli, jednoznačně nezodpovídají ani ti autoři, kteří se zabývají kritikou, prrípadně obhajobou Grayovy teorie. Například Crowder je v tomto ohledu přesvědčen, že Grayova pozice by měla být označována jako antiliberalismus, což je dle něho zřejmé z těch pasáží, v nichž Gray prohlašuje, že liberální, potažmo osvícenský projekt dostal smrtelnou ránu a příchod post-liberalismu je nedaleko. ${ }^{84} \mathrm{~S}$ tímto názorem ovšem evidentně nesouhlasí Horton, když zdůrazňuje, že Gray svým stanovením univerzálního minima - i navzdory soustavné kritice univerzalistických tendencí liberalismu - rovněž připouští určitý typ univerzalismu, $\mathrm{v}$ důsledku čehož má Gray k převažujícímu proudu liberalismu blíže, než sám připouští. ${ }^{85}$ Ačkoli Horton spolu s Neweym reflektují četnou kritiku Grayovy politické koncepce, prŕípadně jsou sami jejími neúprosnými posuzovateli, vzhledem ke Grayovu neustálému promýšlení nedostatků liberálního myšlení, jakož i k autorově snaze o jeho revizi prostřednictvím alternativní teorie modu vivendi, řadí oba autoři Graye přímo $\mathrm{k}$ tradici liberalismu. ${ }^{86}$ Jeremy Shearmur pak $\mathrm{v}$ souvislosti s Grayovou politickou koncepcí upozorňuje na nutnost odlišovat jeho substanciální názory, jež směřují k vypracování liberálních pojmů, od názorů týkajících se způsobu argumentace v politické filosofii, respektive konkrétního charakteru a možností dané teorie. Jak Shearmur postuluje, přinejmenším s ohledem na substanciální úhel pohledu je Gray klasický liberál s jistými pluralistickými a konzervativními tendencemi. $^{87}$

Domnívám se, že se stanoviskem posledního zmíněného autora je možné souhlasit, nebot' Gray zůstává ve své podstatě liberálem, a to i přes veškerou svou argumentaci orientovanou proti liberalismu. Dle mého soudu totiž jeho kritika nemírí ani tak na konkrétní hodnoty a principy liberalismu jako spíše na otázku po rozsahu a možnostech liberální politické teorie, jež si činí ve své univerzalistické podobě prŕliš vysoké nároky, směřjící k vytlačení samotného politična z politické reality. Jsem přesvědčena, že k tomuto tvrzení přispívá i Grayovo označení vlastní teorie modu vivendi jako neohobbesovské koncepce - byt' Gray reflektuje, že takové vymezení ještě

\footnotetext{
${ }^{83}$ Blíže viz Heywood (2005, s. 39-40).

${ }^{84}$ Crowder (2007, s. 63).

${ }^{85}$ Horton (2007, s. 43).

${ }^{86}$ Horton \& Newey (2007, s. 3).

${ }^{87}$ Shearmur (2007, s. 82).
} 
palčivěji vzbuzuje otázku, jestli lze modus vivendi chápat jako verzi liberalismu. ${ }^{88}$ Přesto či možná právě proto se autor k tomuto označení uchyluje, nebot' tak dle mého názoru zdůrazňuje stěžejní politický motiv jím formulované teorie a její odlišnost od univerzalistického pojetí liberalismu. Právě důraz na politično totiž Graye přivádí k Hobbesovi, který na rozdíl od univerzalistického liberalismu neodvozuje legitimitu státu na základě všeobjímajících etických principů, nýbrž ryze minimalisticky prostřednictvím strachu a lidských vášní, čímž umožňuje naplnit základní úkol státu, a sice dosažení bezpečí a mírového soužití. Grayovo odmítání liberalismu jako univerzalistické doktríny přitom svědčí o tom, že cílem jeho politické teorie není vyvrátit správnost liberalismu jako takového, nýbrž spíše nahradit nevyhovující způsob výstavby liberální teorie, při jejímž obvyklém utváření není v otázce jejích klíčových principů brána $\mathrm{v}$ potaz ani historická realita, ani každodenní praxe.

\section{Politično jako základ modu vivendi}

Ačkoli je třeba připustit, že ve vývoji Grayova myšlení lze nalézt mnoho motivů - od hodnotového pluralismu, univerzálních forem dobra a zla, ideálu tolerance přes odmítnutí osvícenské víry $\mathrm{v}$ humanismus, pokrok a nadřazenost rozumu až po kritiku socialismu, konzervatismu a v neposlední řadě také liberální tradice - domnívám se, že Grayovy závěry ohledně společného soužití lidských bytostí nejsou přehnaně rozsáhlé. Gray totiž ve své teorii dospívá k poměrně jednoduchému závěru, a sice že existuje mnoho forem dobra, a tedy i mnoho životních způsobů, jež lze pokládat za dobré, přičemž tyto nelze jakkoli sloučit a utvořit z nich jeden ideální způsob života, prŕípadně univerzálně platný a tím i nadřazený ideál dobra. Z toho důvodu jsou lidé nuceni činit radikální a někdy i tragické volby, jejichž odstranění by však bylo pošetilé, nebot' právě konflikty hodnot a životních způsobů jsou přirozeným zdrojem našeho etického života. Jestliže přitom budeme konflikty hodnot řešit spíše politicky než pouze v rovině čisté teorie a budeme-li navíc ctít toleranci jako podmínku pro dosažení mírové koexistence, jsme na nejlepší cestě $\mathrm{k}$ vytvoření modu vivendi jakožto ideálu přizpůsobeného historickým podmínkám pluralismu. Ačkoli Gray těmito postuláty nenabízí nikterak široké spektrum principů a zásad, dle mého názoru formuluje sice minimalistickou, ale $\mathrm{v}$ podstatě soudržnou politickou teorii modu vivendi, jejímž signifikantním znakem je jak úsilí o stanovení limitního rozsahu možné působnosti politické teorie, tak zachování politična, a tudíž i prostoru pro ryze politická řešení morálních a politických konfliktů.

Jeden z problémů znesnadňujících porozumění Grayově teorii spočívá $\mathrm{v}$ charakteru mnohých klíčových postulátů autora, jež jsou vyjádřeny natolik implicitně, že ponechávají př́liš velký prostor pro rozdílnou interpretaci či úplné zpochybnění.

${ }^{88}$ Gray (2007, s. 221). 
Ačkoli se Grayovi dle mého soudu podařilo odhalit, v čem spočívají meze a nedostatky liberalismu, když tematizoval jeho přílišné univerzalistické, melioristické, individualistické a egalitaristické tendence, je třeba konstatovat, že v Grayově teorii chybí explicitnější vyjádření zcela stěžejního důrazu kladeného na morální zatížení liberalismu, jež vede k potlačení bytostného politična. Podobnou obtíž spatřuji i v souvislosti s Grayovým vymezením univerzálního minima, respektive univerzálních forem dobra a zla. Přestože Gray tvrdí, že existují univerzální lidská dobra a zla, ${ }^{89}$ o konkrétní podobě oněch univerzálních dober se $\mathrm{v}$ podstatě $\mathrm{z}$ autorovy teorie nic nedozvídáme, nebot' Gray k jejich specifickému „uchopení“ dospívá negativním způsobem, když hovoří o existenci univerzálních forem zla, aniž by ovšem tento svévolný přechod od dobrého ke zlému výslovně odůvodnil. Jistou paralelu k tomuto Grayovu př́stupu nalézáme opět u Williamse, který se ovšem ke svému východisku explicitně přiznává, když podobně jako Gray zavrhuje možnost dospět k nejvyššímu dobru a přichází s myšlenkou jeho nahrazení představou nejvyššího zla, na němž se lidé spíše shodnou. Dle Williamse proto platí, že základní lidská práva bychom neměli zakládat na sporných tezích liberalismu či jakékoli jiné ideologie, nýbrž měli bychom v této otázce

„do nejvyšší možné míry spoléhat na rozpoznání hlavních zel ... a na své nejlepší kritické chápání toho, co dnes lze počítat za legitimizování, a na to, co v moderních podmínkách z těchto zjištění vyplývá““.90

Jak bylo naznačeno v této studii, domnívám se, že jedním ze způsobů, jak docílit lepšího přijetí Grayovy koncepce, je její reformulace s ohledem na již zmíněný druh liberálního myšlení, a sice liberalismus strachu. Gray by se tak připojil k myslitelům jako je např́klad Bernard Williams i další autoři, hlásící se otevřeně k odmítání utopických vizí spjatých s formulováním určité ideální teorie či morálních principů, jež by byly považovány za prvotní a na jejichž základě by byl až posléze vystavěn dobrý život. Gray totiž prostřednictvím své teorie modu vivendi stejně jako představitelé liberalismu strachu odmítá prosazování moralismu v politických teoriích, a naopak usiluje o realistický př́istup umožňující zachování politična. Domnívám se, že ve chvíli, kdy by Gray upustil od svého zarputilého zavrhování univerzalismu, který do značné míry beztak připouští, když v zájmu předcházení obviněním z relativismu vymezuje předpoklad univerzálního minima, mohl by přijmout univerzalismus, jenž je vlastní liberalismu strachu, aniž by tím výrazně slevil ze svých požadavků na odlišení vlastní teorie modu vivendi od převažujícího univerzalistického pojetí liberalismu. Jak vysvětluje Williams, univerzální charakter liberalismu strachu spočívá v tom, že

${ }^{89}$ Gray (2004, s. 17).

${ }^{90}$ Williams (2011, s. 124-125). 
„hovoří k celému lidstvu a má na to ... jedinečné právo, nebot' pracuje s jedinými zcela jistě univerzálními politickými záležitostmi: mocí, bezmocí, strachem, krutostí a univerzálností záporných vlastností‘ “.91

Liberalismus strachu pak propojuje tento jemu vlastní univerzalismus s antiuniverzalistickým postojem akcentujícím nutnost praktického i pojmového zakotvení liberálních postupů v každé konkrétní historické situaci, a to tak, že neustále klade důraz na existenci politické reality jakožto prvotní a všudypřítomné skutečnosti. ${ }^{92}$

S podobným anti-univerzalistickým názorem se prritom ve své teorii bezpochyby ztotožňuje i Gray, když odmítá přístup univerzalistického liberalismu, jenž vytváří nadčasové morální a politické ideály platné bez ohledu na historické okolnosti. Jak ovšem předpokládám, Grayova politická teorie implicitně zahrnuje rovněž univerzalismus liberalismu strachu, nebot' podobným negativním zpo̊sobem, jakým tento směr dochází k univerzálním politickým záležitostem, vysvětluje i Gray existenci univerzálních forem zla, jež jsou na základě lidské přirozenosti stejné pro všechny lidské bytosti. Rozdíl mezi teoretiky liberalismu strachu a Grayem je tedy v tomto ohledu spíše argumentační, jelikož Gray dospívá k univerzálním formám zla prostřednictvím antropologických předpokladů, zatímco zastánci liberalismu strachu formulují svůj univerzalismus na základě politických argumentů. Konečná vyznění vyplývající z těchto uvedených forem univerzalismu jsou nicméně totožná, jelikož jak $\mathrm{v}$ př́padě liberalismu strachu, tak i $\mathrm{v}$ Grayově koncepci směřují tyto závěry „williamsovsky“ řečeno - ke splnění základního požadavku legitimizace. Pro Grayovu politickou teorii je totiž stejně jako pro liberalismus strachu primární zabezpečit společnost před těmi formami zla, na nichž se všichni lidé shodnou, přičemž až poté, co bude tento požadavek splněn, lze zvažovat a rozvíjet další dobra. Nutno dodat, že požadavek legitimizace není, jak píše Williams, principem morálním, nýbrž ryze politickým, nebot' představuje podmínku existence samotné politiky. ${ }^{93}$ To je dle mého názoru pro revizi Grayovy teorie modu vivendi stěžejní tvrzení, jelikož pokud budeme trvat na důležitosti toho aspektu autorovy koncepce, jenž odmítá morální zatížení liberální teorie a prosazuje zachování bytostného politična, ukazuje se krok směrem k liberalismu strachu jako přijatelné a vcelku logické rozvíjení Grayovy politické teorie.

\section{Literatura}

Crowder, G. (2007): „Gray and the Politics of Pluralism.“ In The Political Theory of John Gray, eds. J. Horton \& G. Newey, Routledge, London, 2007, s. 59-76.

\footnotetext{
${ }^{91}$ Tamtéž, s. 105.

${ }^{92}$ Tamtéž, s. 108.

${ }^{93}$ Tamtéž, s. 33.
} 
Gray, J. (2004): Dvě tvářre liberalismu. Mladá fronta, Praha.

Gray, J. (1995): Enlightenment's Wake. Politics and Culture at the Close of the Modern Age. Routledge, London.

Gray, J. (1999): Liberalismus. Občanský institut, Praha.

Gray, J. (1993): Post-Liberalism: Studies in Political Thought. Routledge, London.

Gray, J. (2007): „Reply to Critics.“ In The Political Theory of John Gray, eds. J. Horton \& G. Newey, Routledge, London, 2007, s. 211-235.

Gray, J. (2000): „Two Liberalisms of Fear.“ The Hedgehog Review 2 (1): 9-23.

Hay, C. (2002): Political Analysis. Palgrave, Basingstoke.

Hejduk, T. (2011): „Doslov.“ In Na počátku byl čin, B. Williams, Pavel Mervart, Červený Kostelec.

Heywood, A. (2005): Politická teorie. Eurolex Bohemia, Praha.

Hobbes, T. (2009): Leviathan aneb látka, forma a moc státu církevního a politického. OIKOYMENH, Praha.

Horton, J. (2007): ,John Gray and the Political Theory of Modus Vivendi.“ In The Political Theory of John Gray, eds. J. Horton \& G. Newey, Routledge, London, 2007, s. 43-58.

Horton, J. \& Newey, G. (2007): „John Gray: A Political Theorist Of and Against Our Times.“ In The Political Theory of John Gray, eds. J. Horton \& G. Newey, Routledge, London, 2007, s. 1-4.

Jones, P. (2007): „Toleration, Value-pluralism, and the Fact of Pluralism.“ In The Political Theory of John Gray, eds. J. Horton \& G. Newey, Routledge, London, 2007, s. 77-98.

Rawls, J. (1993): Political Liberalism. Columbia University Press, New York.

Shearmur, J. (2007): „Gray's Progress: From Liberalisms to Enlightenment's Wake.“ Journal for Libertarian Studies 21 (3): 79-114.

Taylor, Ch. (1997): „Nedorozumění v diskusi mezi liberály a komunitaristy.“ In Současná politická filosofie, ed. J. Kis, OIKOYMENH, Praha, 1997, s. 465-494.

Williams, B. (2011): Na počátku byl čin. Pavel Mervart, Červený Kostelec. 